OPEN ACCESS

Edited by:

Nuno Sousa,

Instituto de Pesquisa em Ciências da

Vida e da Saúde (ICVS), Portugal

Reviewed by:

Maria Cubel,

Brunel University London,

United Kingdom

Susana Roque,

University of Minho, Portugal

${ }^{*}$ Correspondence:

Petr Houdek

petr.houdek@gmail.com

Received: 19 June 2017

Accepted: 09 April 2018

Published: 01 May 2018

Citation:

Houdek P (2018) Economic Holobiont: Influence of Parasites, Microbiota and Chemosignals on

Economic Behavior.

Front. Behav. Neurosci. 12:77. doi: 10.3389/fnbeh.2018.00077

\section{Economic Holobiont: Influence of Parasites, Microbiota and Chemosignals on Economic Behavior}

\author{
Petr Houdek* \\ Faculty of Social and Economic Studies, Jan Evangelista Purkyně University in Ústí nad Labem, Ústí nad Labem, Czechia
}

The article is a perspective on utilization of microorganisms and chemosignals in studying human economic behavior. Research in biological roots of economic development has already confirmed that parasitic pressure influenced the creation and development of cultural norms and institutions. However, other effects of microorganisms on human groups and individual decision-making and behavior are heavily understudied. The perspective discusses how parasitic infections, sexually transmitted organisms and microbiota (i.e., "human holobiont") could causally influence risk-seeking behavior, impulsivity, social dominance, empathy, political views and gender differences. As a case study, the parasite Toxoplasma gondii and its influence on economic preferences, personal characteristics and human appearance are examined. I also briefly review how chemosignals influence decision-making, particularly in the social preferences domain. I mention some predictions that arise from the paradigm of economic holobiont for the economic science. The conclusion summarizes limitations of the discussed findings and the stated speculations.

Keywords: microbiota, chemosignaling, Toxoplasma gondii, parasites, risk preferences, time preferences, social preferences, economics

\section{INTRODUCTION}

No man is an island, entire of itself. His/her life is shaped by microorganisms (archaea, viruses, bacteria, protozoa) which help him/her digest food, synthesize important vitamins and fight against harmful microorganisms. Some microorganisms have developed the ability to affect our nervous and hormonal systems (Adamo, 2013; Mayer et al., 2014; Kramer and Bressan, 2015; Stilling et al., 2016; Allen et al., 2017).

Knowledge of the influence of microorganisms on specific long-term changes of human behavior, or personality dates back at least to the first descriptions of rabies. The infected individuals experience hydrophobia, which allows the virus to stay longer in their saliva, because they don't drink, and they swallow less. Infected subjects then begin exhibiting aggressive behavior, which contributes to the transmission of the virus through bites (Baer, 1991). Impaired serotonin neurotransmission may account for the aggressive behavior (Jackson, 2016). The aim of this article is to show that plenty of other mind-altering microorganisms exist which, by more diminutive manipulations of the nervous and hormonal system, influence human behavior in areas that are of the interest of economics. For an overview, see Table 1. 


\section{IMPACT OF MICROORGANISMS ON HUMAN CULTURES, VALUES AND INDIVIDUAL BEHAVIOR}

It is impossible to overrate the influence of parasites if they could be the driving forces of evolution in general (Decaestecker et al., 2007) as well as the evolution of sex (Hamilton et al., 1990). Microbes also possibly shaped the high level of human cooperation and socialization. The explanation stems from the fact that selective pressure favors those microbes that achieve higher interaction among their hosts-horizontal transmission is then the most effective (Lewin-Epstein et al., 2017). Their impact on human cultures, institutions, and individual decision-making should thus be applied more broadly in economics (even if we omit the direct impact of diseases on human capital, saving, worker productivity, or medical costs; Sachs and Malaney, 2002; Eppig et al., 2010, 2011).

There is an already existing literature about the influence of parasite and infection stress on the development of cultural norms and values of individuals, respectively (Fincher and Thornhill, 2012; Spolaore and Wacziarg, 2013). High prevalence of infections correlates with conformity, preservation of cultural norms, and xenophobia; put simply, cultural norms operate as prescriptions to avoid illness (Schaller et al., 2015). Consequently, there are lower mean levels of socio-sexuality, extraversion, and openness in regions with higher levels of infectious diseases (Schaller and Murray, 2008). Parasite stress strengthens family ties and religiosity, because in-group assortative sociality makes it easier to avoid infection from novel parasites (Fincher and Thornhill, 2012). Relatedly, national parasite stress strengthens traditionalism, i.e., conservative adherence to group norms (Tybur et al., 2016). However, the conclusions of the pathogen stress theory are controversial, since different authors suggest distinct interpretations (Hackman and Hruschka, 2013; Hruschka and Henrich, 2013; Hruschka and Hackman, 2014); also see "Sexually Transmitted Diseases and Beauty Premium, Impulsivity and Personality Disorders" section.

The prevalence of toxoplasmosis (see "Toxoplasma gondii" section) seems to be associated with neuroticism, uncertainty avoidance and masculinity at national levels (Lafferty, 2006). In development economics, Maseland used the national prevalence of Toxoplasma gondii as an instrument for cultural variation. "Increased vigilance and reduced moral consciousness make [Toxoplasma-infected] people more opportunistic and suspicious of the behavior of others, reducing cultural trust levels in society... lower self-confidence makes people less willing to stand up to authorities and pessimistic about the success of social interactions." (Maseland, 2013). The study suggests that cultural effects of higher prevalence of $T$. gondii could be a strong predictor of institutional quality and long-term economic performance.

\section{Toxoplasma gondii}

Most studies about the influence of parasites on individual human decision-making concern toxoplasmosis, caused by the protozoan parasite T. gondii (Webster, 2001; Flegr, 2013b, 2017; Houdek, 2017a,b). T. gondii infects about one third to one half of the human population and, unlike many other infectious diseases, it is widely spread in developed countries; more than 1 million new infections are estimated to occur each year in the United States (Jones and Holland, 2010). In immune-competent humans, infection by $T$. gondii is asymptomatic or manifest with mild flu-like symptoms (Weiss and Dubey, 2009).

T. gondii gained the ability to manipulate its host (typically mice, however potentially any warm-blooded animal) and to transmit to its definitive host (any feline species) by predation. The manipulative abilities of $T$. gondii manifest in both direct effects-infected mice have slower reactions (Webster, 2007), and they exhibit complex changes in behavior-infected mice lose fear of cats and cat urine starts attracting them (Berdoy et al., 2000; Flegr and Markoš, 2014). The manipulation of mice results in the parasite getting a higher chance of entering its final host, where it can sexually reproduce. The same effects are observed in humans-their reactions are slower (Havlícek et al., 2001) and attractiveness of cat odor increased for infected men but decreased for infected women (Flegr et al., 2011).

T. gondii is able to manipulate the neuroendocrine system, affects metabolism of dopamine (Prandovszky et al., 2011) and probably testosterone (Lim et al., 2013) and serotonin (Flegr, 2013a). The studies also identified correlation between toxoplasmosis and several mental illnesses (whose occurrence is connected with the aforementioned hormones and neurotransmitters): schizophrenia (Torrey et al., 2012), autism (Prandota, 2010), mood disorders (Pearce et al., 2012) and suicidal inclination (Ling et al., 2011); but see Sugden et al. (2016).

Toxoplasma-positive people (i.e., Toxoplasma-seropositive individuals) have an increased risk of traffic and work accidents (Flegr et al., 2002; Alvarado-Esquivel et al., 2012), and various impairments of cognitive functions (Gale et al., 2015). Infected individuals manifest a decreased tendency for novelty seeking, decreased conscientiousness and higher extraversion (Flegr et al., 2003; Skallová et al., 2005; Lindová et al., 2012). Some personality changes are in the opposite direction in men and women (Flegr, 2010). For instance, Toxoplasma-positive men had lower superego strength and protension (Flegr and Hrdý, 1994), whereas Toxoplasma-positive women score higher in affectothymia, alaxia and untroubled adequacy and self-sufficiency (Flegr et al., 1996). Nevertheless, toxoplasmosis is also associated with higher aggression among women (but not among men) and with higher impulsive sensation-seeking among younger men (Cook et al., 2015). On the other hand, our research shows that infected people are more patient, and the association is mediated by the $\mathrm{Rh}$ blood group (Houdek et al., 2017); while RhD heterozygotes are protected against negative effects caused by $T$. gondii infection (Novotná et al., 2008). In general, the intensity of parasite manipulations of the hosts (i.e., their cognitive impairments, personality changes) amplifies with the length of the infection, implying possible causal influence of the parasite (Flegr, 2013b). 
TABLE 1 | Examples of the influence of parasites, microbiota and chemosignals on economic decision-making.

\section{Classes of deviances}

from the standard economic

model (DellaVigna, 2009)

Nonstandard preferences
Time preferences (self-control problems)

Risk preferences

Social preferences

Overconfidence or anxiety

Social pressure

Nonstandard decision-making Limited attention
Nonstandard beliefs

Examples of possible influence of parasites, microbiota and chemosignals on the behavior and decision-making

Higher impulsive sensation-seeking among Toxoplasmapositive younger men (Cook et al., 2015)

Lower diversity in gut microbiome could be associated with more impulsive behavior (Alcock et al., 2014)

Toxoplasma-positive subjects have lower novelty-seeking scores (Skallová et al., 2005)

Exposure to anxiety odor/chemosignal increases risk taking behavior (Haegler et al., 2010)

Toxoplasma-positive men are less cooperative, Toxoplasmapositive women are more cooperative (Lindová et al., 2010) Exposure to anxiety odor/chemosignal recruits empathyrelated brain areas (Prehn-Kristensen et al., 2009)

Probiotic formulation reduces aggressive thoughts (Steenbergen et al., 2015)

Toxoplasma-positive subjects have higher extraversion and lower conscientiousness (Lindová et al., 2012)

Odor/chemosignals of aggression can induce an anxiety reaction (Mutic et al., 2016)

Toxoplasma gondii weakens long-term ability to concentrate (Havlícek et al., 2001)

Exposure to fear odor/chemosignal enhances vigilance in women (Chen et al., 2006)

Prevalence of latent toxoplasmosis explains neuroticism, uncertainty avoidance, and masculinity at national levels (Lafferty, 2006)

Odor/chemosignals induce fear, disgust and happiness contagion in women (de Groot et al., 2012, 2015)

Probiotic formulations alleviate psychological distress (Messaoudi et al., 2011)

Administration of a bacteria (Mycobacterium vaccae) may build resilience and improve emotional responses under stress (Siebler et al., 2018)

National parasite stress could strengthen traditionalism (Tybur et al., 2016)

Toxoplasma-positive men have lower superego strength and protension (Flegr and Hrdý, 1994)
As far as I know, only a few laboratory experiments with real incentives observed the influence of $T$. gondii on economic decision-making. In the Dictator Game, infected men were less generous, and in the Trust Game, women were more trusting, however, the effects were small or insignificant (Lindová et al., 2010). An insignificant influence of toxoplasmosis on risk attitude and loss aversion in a small sample of women is reported by Lanchava et al. (2015). If the effects of toxoplasmosis are real, there is an untapped opportunity to use it as a variable in studies about the impact of cognitive skills, personality traits, or non-cognitive skills on labor market outcomes, job (self-)selection, entrepreneurship, well-being, et cetera (Bowles et al., 2001; Knudsen et al., 2006; Borghans et al., 2008; Chiteji, 2010; Cubel et al., 2016).

In some cases, toxoplasmosis demonstrates a different effect on men and women. The reasons for these differences remain unknown insofar; however, they could be different physiological mechanisms responsible for the stress response (Lindová et al., 2006). It is possible to use T. gondii in research on gender differences (Croson and Gneezy, 2009)-e.g., to see whether a higher gender pay gap exists in areas, sectors and companies with a higher prevalence of toxoplasmosis.

Moreover, there are many more microbes that affect humans similarly, e.g., chlorovirus is associated with a decrease in cognitive functioning (Yolken et al., 2014), cytomegalovirus ( $\beta$-herpesvirus) could cause depression, anxiety and increase overall psychological morbidity (Phillips et al., 2008). Other infectious agents could have similar impacts (Wang et al., 2014). On the other hand, research (insofar on mice) shows that some infections could improve stress-related emotional behavior (Lowry et al., 2007) and even induce antidepressant-like responses (Siebler et al., 2018).

\section{Sexually Transmitted Diseases and Beauty Premium, Impulsivity and Personality Disorders}

In theory, hosts may express more adaptive behavior and traits when infected by parasites (Weinersmith and Earley, 2016). 
The logic of evolution commands that sexually transmitted parasites, bacteria and viruses could enhance the sexual attractiveness of their hosts, because that way they achieve a higher chance of transmission to another host.

Sporadic evidence exists that $T$. gondii (which can be in some cases sexually transmitted; Flegr et al., 2014) enhances sexual attractiveness of infected brown rats males (Hari Dass and Vyas, 2014). Although the mechanism of achieving higher sexual attractiveness in the infected individuals is yet to be discovered, there are independent findings that $T$. gondii increases the level of testosterone in male rats (Lim et al., 2013). Men infected by $T$. gondii have higher body height, and are perceived as more dominant and masculine by women, a trait positively correlated with testosterone levels (Flegr et al., 2005; Hodková et al., 2007). These findings support the possibility that the higher level of testosterone in infected men could be the consequence of the infection and, ultimately, the result of the parasite's host manipulation to transmit easily by sexual intercourse. Since testosterone relates to risk-seeking behavior, social dominance, lower empathy, reduced cognitive reflection, and so on (Apicella et al., 2008; Coates and Herbert, 2008; Rilling and Sanfey, 2011; Nave et al., 2017), a speculation arises whether Toxoplasma-positive subjects manifest these traits more intensely.

As humans can be infected by many bacterial and viral Sexually Transmitted Diseases (STDs), there is an unexploited opportunity to examine whether some of the microorganisms enhance the (sexual) attractiveness of their host (Heil, 2016) and provide another advantage for him. The potential parasite influence on attractiveness could impact many economic variables, in which influence of attractiveness was observed (Hamermesh and Biddle, 1994; Langlois et al., 2000) gaining a job position (Ruffle and Shtudiner, 2015), higher earnings (Scholz and Sicinski, 2015), probability of election to a political seat (Berggren et al., 2010) or the size of debt interest rate (Ravina, 2012); but see Kanazawa and Still (2017).

Anything that makes hosts have promiscuous sex more often will be beneficial to STDs. It could be speculated that STDs could cause positive attitudes toward sex, lower xenophobia and conservatism, increased dominance in men, increased submissiveness in women; higher impulsivity and creativity, lower conscientiousness and more personality disorders to disrupt long-term relationships in favor of short-term ones, et cetera (Miller and Fleischman, 2016).

\section{MICROBIOTA, GUT-BRAIN AXIS}

It is surprising that the impact of food on economic decisionmaking is not widely studied. So far, it was reported that, for instance, eating spicy food increases risk taking (Wang et al., 2016), bitter taste was found to promote hostility (Sagioglou and Greitemeyer, 2014), sweet taste should increase agreeableness and helping behavior (Meier et al., 2012), etc. However, apart from some sort of priming, the studies do not present any theory that would physiologically explain why the phenomena occur. The aim of this section is to suggest an inspirational association between microbiome and human behavior.
Our intestinal tract is packed with up to 40 trillion microbes (Sender et al., 2016), and because we are born germfree, the microbes have to come from the outside world (Ley et al., 2006). During and after birth, the newborn is populated with indigenous microbes (Dominguez-Bello et al., 2010). The microbiota (microbes living inside us and on us) then systematically affect development and function of organs, including the brain (the gut-brain axis is a bidirectional communication channel via neural, endocrine, and immune pathways; Mayer et al., 2014). Although gut microbiota doesn't change much during adulthood, there are significant differences in its composition among people as well as cultures (Wu et al., 2011). The impact of geography and culture on alimentation is obvious, nevertheless, there is no study that examines the impact of microbiota on human culture.

As demonstrated by Lozupone et al. (2012): "Classification of people as lean or obese can be made solely on the basis of their gut microbiota with $90 \%$ accuracy," and the causal effect can be discussed: "... mice that were raised germ-free and then colonized with the microbiota from an obese mouse gained fat more rapidly than those colonized with the microbiota of a lean mouse". The absence of the right bacteria leads to an abnormal organ function (Heijtz et al., 2011). A study demonstrated that germ-free mice manifest abnormal physiological reactions to stress. This state is however reversible by probiotic-induced recolonization with bacteria Bifidobacterium infantis (Sudo et al., 2004). Microbiota produce neurochemicals which are analogical to the mammalian ones and which impact mood and behavior; e.g., 50\% of dopamine and the majority of serotonin have an intestinal source. It was also proven that microbes change the receptor expression and a range of neural mechanisms (for reviews, see Alcock et al., 2014; Mayer et al., 2014). Gut microbiota profiles are associated with differences in emotional and attentional processing (Tillisch et al., 2017) and with deficits in normal social behavior (Sherwin et al., 2017). A study (Desbonnet et al., 2014) has found significant social impairments in germ-free mice, particularly in males.

Microbiota are possible to manipulate by probiotics, antibiotics, or dietary interventions offering an easy approach to study their influence on economic preferences and behavior; for example in cooperation (Rabin, 1993), trust (Fehr, 2009) and deception (Gneezy, 2005) games. The exact impact of microbiota on human decision-making is a matter of research in progress, however, an implication from the few pilot studies can be drawn (Kramer and Bressan, 2015; Sandhu et al., 2017)—as in case of mice, microbiota can have an impact on mood, cognitive functions and processing of social signals. It was found that e.g., probiotic formulations alleviate psychological distress (Messaoudi et al., 2011) and reduce cognitive reactivity to sad mood by reducing aggressive thoughts (Steenbergen et al., 2015).

\section{CHEMOSIGNALS}

The parasite Plasmodium falciparum, which causes malaria, is able to make its human host more attractive for its vector, the 
mosquito Anopheles gambiae, which enhances the probability of being transmitted (Lacroix et al., 2005). The mechanism underlying this manipulation is yet unknown, but the parasites likely change the infected individual's breath or body odor (or it's intensity by fever). The effect of chemosignals, being odors produced by the human body, is not restricted only to the parasite's manipulative efforts. Based on animal studies, Archie and Tung (2015) conclude: "[M]icrobes can also affect host's social behavior. One of the main ways these effects arise is through chemical signals: considerable evidence indicates that some animals cultivate odor-producing bacteria in their scent glands... [There are] correlations between host traits (e.g., sex, dominance rank, social group membership), the bacterial communities living in scent glands, and the volatile compounds that emerge from these glands".

In case of humans, Semin and de Groot (2013) state that neuronal processing of human body odor differs from non-endogenous odors due to skin-gland excretions and bacterial activity. Therefore, it is possible to discuss that human chemosignals are processed through neuronal relays responsible for the processing of social information (and not only within olfactory brain areas). That allows them to gain a stronger social dimension. Moreover, humans (along with e.g., dogs or rats) are extremely capable of odor detection, they are able to detect odorants at concentrations as low as three droplets in an Olympic-size swimming pool (Yeshurun and Sobel, 2010).

I do not know of any economic study that observes changes in behavior based on the odor of others. However, psychological studies have already shown that happiness (de Groot et al., 2015), fear, or disgust (Zhou and Chen, 2009; de Groot et al., 2012) can be transferred by the means of odors. Even sniffing negative-emotion-related odorless tears from women can reduce men's sexual arousal, and salivary levels of testosterone (Gelstein et al., 2011). On the other side, a small study (Mutic et al., 2016) used body odor of men in a boxing session, in which they naturally behave aggressively with the goal to harm, to produce an anxiety-related stress response in participants. This relation is also applicable vice versa: anxiety chemosignals induce higher risk taking behavior (Haegler et al., 2010). Naturally, human chemosignals play a crucial role in human mate choice, sexuality and mother-infant bonding (Lübke and Pause, 2015).

de Groot et al. (2017) summarize the existing evidence: "[H]uman odorants become a medium by means of which information about dynamic states (e.g., emotions...) and enduring characteristics (e.g., age, gender, individuality, personality) can be transferred from a sender to a receiver." The possible applicability of these findings in organization and labor economics or human resources management studies is clear. Furthermore, it could be used in marketing and sales.

\section{REFERENCES}

Adamo, S. A. (2013). Parasites: evolution's neurobiologists. J. Exp. Biol. 216, 3-10. doi: $10.1242 /$ jeb. 073601
For instance, by measuring 100 trace gas species in a cinema, a study found out that specific film events, namely "suspense" or "comedy" caused viewers to change their emission of chemosignals (Williams et al., 2016). It concludes that the odors generated by the audience have a potential to alter the viewers' rating of a movie.

\section{CONCLUSION}

The article introduced several recommendations on how economic research of judgment and decision-making could use the knowledge of influence of parasites, microbiota and chemosignals on human behavior. The proposed speculations have many limitations. The reported studies are usually smallscale, underpowered, non-preregistered, and using a very specific sample of participants. They are based on questionnaires with hypothetical choices, they use multiple testing, selective reporting, etc. Therefore, there is a risk of false-positive results and overrating of the effects due to publication bias (Simmons et al., 2011; Asendorpf et al., 2013; Forstmeier et al., 2017). The predictions of economically relevant effects might not come true. It is crucial not only to replicate these findings, but also to do contextual replications and verify the robustness of the published effects.

Many empirical facts are not sufficiently established or examined as well; e.g., no specific human pheromone has been reliably identified (Wyatt, 2015). Some of the discovered effects contradict each other. Some effects may simply be the result of a prolonged illness. In the case of gut microbiome's influence on the mind, Forsythe et al. (2016) conclude: "there are no clear indications that altering the resident microbiota would be of therapeutic benefit," also a systematic review (Romijn and Rucklidge, 2015) didn't find any evidence for probiotic efficacy in altering psychological outcomes.

\section{AUTHOR CONTRIBUTIONS}

The author confirms being the sole contributor of this work and approved it for publication.

\section{FUNDING}

This work was supported by the Internal Grant Agency of Jan Evangelista Purkyně University in Ústí nad Labem, Czechia.

\section{ACKNOWLEDGMENTS}

I am very grateful to Julie N. Novakova and Markéta Sýkorová for editing the English version of the manuscript. I thank reviewers for their thoughtful, constructive and detailed suggestions, which improved the quality of the manuscript.

Alcock, J., Maley, C. C., and Aktipis, C. A. (2014). Is eating behavior manipulated by the gastrointestinal microbiota? Evolutionary pressures and potential mechanisms. Bioessays 36, 940-949. doi: 10.1002/bies.2014 00071 
Allen, A. P., Dinan, T. G., Clarke, G., and Cryan, J. F. (2017). A psychology of the human brain-gut-microbiome axis. Soc. Personal. Psychol. Compass 11:e12309. doi: $10.1111 /$ spc3.12309

Alvarado-Esquivel, C., Torres-Castorena, A., Liesenfeld, O., Estrada-Martínez, S., and Urbina-Álvarez, J. (2012). High seroprevalence of Toxoplasma gondii infection in a subset of Mexican patients with work accidents and low socioeconomic status. Parasit. Vectors 5:13. doi: 10.1186/1756-33 05-5-13

Apicella, C. L., Dreber, A., Campbell, B., Gray, P. B., Hoffman, M., and Little, A. C. (2008). Testosterone and financial risk preferences. Evol. Hum. Behav. 29, 384-390. doi: 10.1016/j.evolhumbehav.2008.07.001

Archie, E. A., and Tung, J. (2015). Social behavior and the microbiome. Curr. Opin. Behav. Sci. 6, 28-34. doi: 10.1016/j.cobeha.2015.07.008

Asendorpf, J. B., Conner, M., De Fruyt, F., De Houwer, J., Denissen, J. J. A., Fiedler, K., et al. (2013). Recommendations for increasing replicability in psychology. Eur. J. Pers. 27, 108-119. doi: 10.1002/per.1919

Baer, G. M. (1991). The Natural History of Rabies. 2nd Edn. Boston: CRC Press.

Berdoy, M., Webster, J. P., and Macdonald, D. W. (2000). Fatal attraction in rats infected with Toxoplasma gondii. Proc. R. Soc. B Biol. Sci. 267, 1591-1594. doi: $10.1098 /$ rspb.2000.1182

Berggren, N., Jordahl, H., and Poutvaara, P. (2010). The looks of a winner: beauty and electoral success. J. Public Econ. 94, 8-15. doi: 10.1016/j.jpubeco.2009. 11.002

Borghans, L., Duckworth, A. L., Heckman, J. J., and Ter Weel, B. (2008). The economics and psychology of personality traits. J. Hum. Resour. 43, 972-1059. doi: 10.1353/jhr.2008.0017

Bowles, S., Gintis, H., and Osborne, M. (2001). Incentive-enhancing preferences: personality, behavior, and earnings. Am. Econ. Rev. 91, 155-158. doi: 10.1257/aer.91.2.155

Chen, D., Katdare, A., and Lucas, N. (2006). Chemosignals of fear enhance cognitive performance in humans. Chem. Senses 31, 415-423. doi: 10.1093/chemse/bjj046

Chiteji, N. (2010). Time preference, noncognitive skills and well being across the life course: do noncognitive skills encourage healthy behavior? Am. Econ. Rev. 100, 200-204. doi: 10.1257/aer.100.2.200

Coates, J. M., and Herbert, J. (2008). Endogenous steroids and financial risk taking on a London trading floor. Proc. Natl. Acad. Sci. U S A 105, 6167-6172. doi: 10.1073/pnas.0704025105

Cook, T. B., Brenner, L. A., Cloninger, C. R., Langenberg, P., Igbide, A., Giegling, I., et al. (2015). "Latent" infection with Toxoplasma gondii: association with trait aggression and impulsivity in healthy adults. J. Psychiatr. Res. 60, 87-94. doi: 10.1016/j.jpsychires.2014.09.019

Croson, R., and Gneezy, U. (2009). Gender differences in preferences. J. Econ. Lit. 47, 448-474. doi: $10.1257 /$ jel.47.2.448

Cubel, M., Nuevo-Chiquero, A., Sanchez-Pages, S., and Vidal-Fernandez, M. (2016). Do personality traits affect productivity? Evidence from the laboratory. Econ. J. 126, 654-681. doi: 10.1111/ecoj.12373

de Groot, J. H. B., Semin, G. R., and Smeets, M. A. M. (2017). On the communicative function of body odors. Perspect. Psychol. Sci. 12, 306-324. doi: $10.1177 / 1745691616676599$

de Groot, J. H. B., Smeets, M. A. M., Kaldewaij, A., Duijndam, M. J. A., and Semin, G. R. (2012). Chemosignals communicate human emotions. Psychol. Sci. 23, 1417-1424. doi: 10.1177/0956797612445317

de Groot, J. H. B., Smeets, M. A. M., Rowson, M. J., Bulsing, P. J., Blonk, C. G., Wilkinson, J. E., et al. (2015). A sniff of happiness. Psychol. Sci. 26, 684-700. doi: 10.1177/0956797614566318

Decaestecker, E., Gaba, S., Raeymaekers, J. A. M., Stoks, R., Van Kerckhoven, L., Ebert, D., et al. (2007). Host-parasite 'Red Queen' dynamics archived in pond sediment. Nature 450, 870-873. doi: 10.1038/nature06291

DellaVigna, S. (2009). Psychology and economics: evidence from the field. J. Econ. Liter. 47, 315-372. doi: 10.1257/jel.47.2.315

Desbonnet, L., Clarke, G., Shanahan, F., Dinan, T. G., and Cryan, J. F. (2014). Microbiota is essential for social development in the mouse. Mol. Psychiatry 19, 146-148. doi: 10.1038/mp.2013.65

Dominguez-Bello, M. G., Costello, E. K., Contreras, M., Magris, M., Hidalgo, G., Fierer, N., et al. (2010). Delivery mode shapes the acquisition and structure of the initial microbiota across multiple body habitats in newborns. Proc. Natl. Acad. Sci. U S A 107, 11971-11975. doi: 10.1073/pnas.1002601107
Eppig, C., Fincher, C. L., and Thornhill, R. (2010). Parasite prevalence and the worldwide distribution of cognitive ability. Proc. R. Soc. B Biol. Sci. 277, 3801-3808. doi: 10.1098/rspb.2010.0973

Eppig, C., Fincher, C. L., and Thornhill, R. (2011). Parasite prevalence and the distribution of intelligence among the states of the USA. Intelligence 39, 155-160. doi: 10.1016/j.intell.2011.02.008

Fehr, E. (2009). On the economics and biology of trust. J. Eur. Econ. Assoc. 7, 235-266. doi: 10.1162/jeea.2009.7.2-3.235

Fincher, C. L., and Thornhill, R. (2012). Parasite-stress promotes in-group assortative sociality: the cases of strong family ties and heightened religiosity. Behav. Brain Sci. 35, 61-79. doi: 10.1017/S0140525X11000021

Flegr, J. (2010). Influence of latent toxoplasmosis on the phenotype of intermediate hosts. Folia Parasitol. 57, 81-87. doi: 10.14411/fp.2010.010

Flegr, J. (2013a). How and why Toxoplasma makes us crazy. Trends Parasitol. 29, 156-163. doi: 10.1016/j.pt.2013.01.007

Flegr, J. (2013b). Influence of latent Toxoplasma infection on human personality, physiology and morphology: pros and cons of the Toxoplasma-human model in studying the manipulation hypothesis. J. Exp. Biol. 216, 127-133. doi: $10.1242 /$ jeb.073635

Flegr, J. (2017). Do Toxoplasma-infected subjects have better leadership skills? Comment on paper "puppet master: possible influence of the parasite Toxoplasma gondii on managers and employees". Acad. Manag. Perspect. 31, 332-338. doi: 10.5465/amp.2017.0109

Flegr, J., Havlíček, J., Kodym, P., Malý, M., and Smahel, Z. (2002). Increased risk of traffic accidents in subjects with latent toxoplasmosis: a retrospective case-control study. BMC Infect. Dis. 2:11. doi: 10.1186/1471-2334-2-11

Flegr, J., and Hrdý, I. (1994). Influence of chronic toxoplasmosis on some human personality factors. Folia Parasitol. 41, 122-126.

Flegr, J., Hrušková, M., Hodný, Z., Novotná, M., and Hanušová, J. (2005). Body height, body mass index, waist-hip ratio, fluctuating asymmetry and second to fourth digit ratio in subjects with latent toxoplasmosis. Parasitology 130, 621-628. doi: 10.1017/s0031182005007316

Flegr, J., Klapilová, K., and Kaňková, S. (2014). Toxoplasmosis can be a sexually transmitted infection with serious clinical consequences. Not all routes of infection are created equal. Med. Hypotheses 83, 286-289. doi: 10.1016/j.mehy. 2014.05.019

Flegr, J., Lenochová, P., Hodný, Z., and Vondrová, M. (2011). Fatal attraction phenomenon in humans-cat odour attractiveness increased for Toxoplasmainfected men while decreased for infected women. PLoS Negl. Trop. Dis. 5:e1389. doi: 10.1371/journal.pntd.0001389

Flegr, J., and Markoš, A. (2014). Masterpiece of epigenetic engineering-how Toxoplasma gondii reprogrammes host brains to change fear to sexual attraction. Mol. Ecol. 23, 5934-5936. doi: 10.1111/mec.13006

Flegr, J., Preiss, M., Klose, J., Havlíček, J., Vitáková, M., and Kodym, P. (2003). Decreased level of psychobiological factor novelty seeking and lower intelligence in men latently infected with the protozoan parasite Toxoplasma gondii. Dopamine, a missing link between schizophrenia and toxoplasmosis? Biol. Psychol. 63, 253-268. doi: 10.1016/s0301-0511(03)00075-9

Flegr, J., Zitková, S., Kodym, P., and Frynta, D. (1996). Induction of changes in human behaviour by the parasitic protozoan Toxoplasma gondii. Parasitology 113, 49-54. doi: 10.1017/s0031182000066269

Forstmeier, W., Wagenmakers, E.-J., and Parker, T. H. (2017). Detecting and avoiding likely false-positive findings-a practical guide. Biol. Rev. 92, 1941-1968. doi: 10.1111/brv.12315

Forsythe, P., Kunze, W., and Bienenstock, J. (2016). Moody microbes or fecal phrenology: what do we know about the microbiota-gut-brain axis? BMC Med. 14:58. doi: 10.1186/s12916-016-0604-8

Gale, S. D., Brown, B. L., Erickson, L. D., Berrett, A., and Hedges, D. W. (2015). Association between latent toxoplasmosis and cognition in adults: a crosssectional study. Parasitology 142, 557-565. doi: 10.1017/s0031182014001577

Gelstein, S., Yeshurun, Y., Rozenkrantz, L., Shushan, S., Frumin, I., Roth, Y., et al. (2011). Human tears contain a chemosignal. Science 331, 226-230. doi: $10.1126 /$ science. 1198331

Gneezy, U. (2005). Deception: the role of consequences. Am. Econ. Rev. 95, 384-394. doi: 10.1257/0002828053828662

Hackman, J., and Hruschka, D. (2013). Fast life histories, not pathogens, account for state-level variation in homicide, child maltreatment, and family ties in the U.S. Evol. Hum. Behav. 34, 118-124. doi: 10.1016/j.evolhumbehav.2012.11.002 
Haegler, K., Zernecke, R., Kleemann, A. M., Albrecht, J., Pollatos, O., Brückmann, H., et al. (2010). No fear no risk! Human risk behavior is affected by chemosensory anxiety signals. Neuropsychologia 48, 3901-3908. doi: 10.1016/j.neuropsychologia.2010.09.019

Hamermesh, D. S., and Biddle, J. E. (1994). Beauty and the labour-market. Am. Econ. Rev. 84, 1174-1194.

Hamilton, W. D., Axelrod, R., and Tanese, R. (1990). Sexual reproduction as an adaptation to resist parasites (a review). Proc. Natl. Acad. Sci. U S A 87, 3566-3573. doi: 10.1073/pnas.87.9.3566

Hari Dass, S. A., and Vyas, A. (2014). Toxoplasma gondii infection reduces predator aversion in rats through epigenetic modulation in the host medial amygdala. Mol. Ecol. 23, 6114-6122. doi: 10.1111/mec.12888

Havlíček, J., Gašová, Z., Smith, A. P., Zvára, K., and Flegr, J. (2001). Decrease of psychomotor performance in subjects with latent 'asymptomatic' toxoplasmosis. Parasitology 122, 515-520. doi: 10.1017/s0031182001 007624

Heijtz, R. D., Wang, S., Anuar, F., Qian, Y., Bjorkholm, B., and Samuelsson, A. (2011). Normal gut microbiota modulates brain development and behavior. Proc. Natl. Acad. Sci. U S A 108, 3047-3052. doi: 10.1073/pnas. 1010529108

Heil, M. (2016). Host manipulation by parasites: cases, patterns, and remaining doubts. Front. Ecol. Evol. 4:80. doi: 10.3389/fevo.2016.00080

Hodková, H., Kolbeková, P., Skallová, A., Lindová, J., and Flegr, J. (2007). Higher perceived dominance in Toxoplasma-infected men-the new evidence for role of increased level of testosterone in toxoplasmosis-associated changes in human behavior. Neuro Endocrinol. Lett. 28, 110-114.

Houdek, P. (2017a). Puppet master: possible influence of the parasite Toxoplasma gondii on managers and employees. Acad. Manag. Perspect. 31, 63-81. doi: $10.5465 / \mathrm{amp} .2015 .0163$

Houdek, P. (2017b). A reply to: do Toxoplasma-infected subjects have better leadership skills? Comment on paper "puppet master: possible influence of the parasite Toxoplasma gondii on managers and employees". Acad. Manag. Perspect. 31, 339-343. doi: 10.5465/amp.2017.0147

Houdek, P., Zouhar, J., and Flegr, J. (2017). Is Toxoplasma gondii Infection Related to Time and Risk Preferences of Humans? Some Evidence for Manipulation Hypothesis. Prague: University of Economics in Prague.

Hruschka, D. J., and Hackman, J. (2014). When are cross-group differences a product of a human behavioral immune system? Evol. Behav. Sci. 8, 265-273. doi: $10.1037 /$ ebs0000013

Hruschka, D. J., and Henrich, J. (2013). Institutions, parasites and the persistence of in-group preferences. PLoS One 8:e63642. doi: 10.1371/journal.pone. 0063642

Jackson, A. C. (2016). Diabolical effects of rabies encephalitis. J. Neurovirol. 22, 8-13. doi: 10.1007/s13365-015-0351-1

Jones, J. L., and Holland, G. N. (2010). Annual burden of ocular toxoplasmosis in the united states. Am. J. Trop. Med. Hyg. 82, 464-465. doi: 10.4269/ajtmh. 2010.09-0664

Kanazawa, S., and Still, M. C. (2017). Is there really a beauty premium or an ugliness penalty on earnings? J. Bus. Psychol. 33, 249-262. doi: 10.1007/s10869017-9489-6

Knudsen, E. I., Heckman, J. J., Cameron, J. L., and Shonkoff, J. P. (2006). Economic, neurobiological and behavioral perspectives on building America's future workforce. Proc. Natl. Acad. Sci. U S A 103, 10155-10162. doi: $10.1073 /$ pnas. 0600888103

Kramer, P., and Bressan, P. (2015). Humans as superorganisms: how microbes, viruses, imprinted genes, and other selfish entities shape our behavior. Perspect. Psychol. Sci. 10, 464-481. doi: 10.1177/1745691615583131

Lacroix, R., Mukabana, W. R., Gouagna, L. C., and Koella, J. C. (2005). Malaria infection increases attractiveness of humans to mosquitoes. PLoS Biol. 3:e298. doi: 10.1371/journal.pbio.0030298

Lafferty, K. D. (2006). Can the common brain parasite, Toxoplasma gondii, influence human culture? Proc. R. Soc. B Biol. Sci. 273, 2749-2755. doi: 10.1098/rspb.2006.3641

Lanchava, L., Carlson, K., Sebánková, B., Flegr, J., and Nave, G. (2015). No evidence of association between Toxoplasma gondii infection and financial risk taking in females. PLoS One 10:e0136716. doi: 10.1371/journal.pone.0136716

Langlois, J. H., Kalakanis, L., Rubenstein, A. J., Larson, A., Hallam, M., and Smoot, M. (2000). Maxims or myths of beauty? A meta-analytic and theoretical review. Psychol. Bull. 126, 390-423. doi: 10.1037//0033-2909.126.3.390
Lewin-Epstein, O., Aharonov, R., and Hadany, L. (2017). Microbes can help explain the evolution of host altruism. Nat. Commun. 8:14040. doi: $10.1038 /$ ncomms 14040

Ley, R. E., Peterson, D. A., and Gordon, J. I. (2006). Ecological and evolutionary forces shaping microbial diversity in the human intestine. Cell 124, 837-848. doi: 10.1016/j.cell.2006.02.017

Lim, A., Kumar, V., Hari Dass, S. A., and Vyas, A. (2013). Toxoplasma gondii infection enhances testicular steroidogenesis in rats. Mol. Ecol. 22, 102-110. doi: $10.1111 /$ mec. 12042

Lindová, J., Kubena, A. A., Sturcová, H., Křivohlavá, R., Novotná, M., Rubešová, A., et al. (2010). Pattern of money allocation in experimental games supports the stress hypothesis of gender differences in Toxoplasma gondiiinduced behavioural changes. Folia Parasitol. 57, 136-142. doi: 10.14411/fp. 2010.017

Lindová, J., Novotná, M., Havlíček, J., Jozífková, E., Skallová, A., Kolbeková, P., et al. (2006). Gender differences in behavioural changes induced by latent toxoplasmosis. Int. J. Parasitol. 36, 1485-1492. doi: 10.1016/j.ijpara.2006. 07.008

Lindová, J., Př́íplatová, L., and Flegr, J. (2012). Higher extraversion and lower conscientiousness in humans infected with Toxoplasma. Eur. J. Pers. 26, 285-291. doi: 10.1002/per.838

Ling, V. J., Lester, D., Mortensen, P. B., Langenberg, P. W., and Postolache, T. T. (2011). Toxoplasma gondii seropositivity and suicide rates in women. J. Nerv. Ment. Dis. 199, 440-444. doi: 10.1097/nmd.0b013e318221416e

Lowry, C. A., Hollis, J. H., de Vries, A., Pan, B., Brunet, L. R., Hunt, J. R. F. et al. (2007). Identification of an immune-responsive mesolimbocortical serotonergic system: potential role in regulation of emotional behavior. Neuroscience 146, 756-772. doi: 10.1016/j.neuroscience.2007.01.067

Lozupone, C. A., Stombaugh, J. I., Gordon, J. I., Jansson, J. K., and Knight, R. (2012). Diversity, stability and resilience of the human gut microbiota. Nature 489, 220-230. doi: 10.1038/nature11550

Lübke, K. T., and Pause, B. M. (2015). Always follow your nose: the functional significance of social chemosignals in human reproduction and survival. Horm. Behav. 68, 134-144. doi: 10.1016/j.yhbeh.2014.10.001

Maseland, R. (2013). Parasitical cultures? The cultural origins of institutions and development. J. Econ. Growth 18, 109-136. doi: 10.1007/s10887-013-9089-x

Mayer, E. A., Knight, R., Mazmanian, S. K., Cryan, J. F., and Tillisch, K. (2014). Gut microbes and the brain: paradigm shift in neuroscience. J. Neurosci. 34, 15490-15496. doi: 10.1523/jneurosci.3299-14.2014

Meier, B. P., Moeller, S. K., Riemer-Peltz, M., and Robinson, M. D. (2012). Sweet taste preferences and experiences predict prosocial inferences, personalities, and behaviors. J. Pers. Soc. Psychol. 102, 163-174. doi: 10.1037/a0025253

Messaoudi, M., Lalonde, R., Violle, N., Javelot, H., Desor, D., and Nejdi, A. (2011). Assessment of psychotropic-like properties of a probiotic formulation (Lactobacillus helveticus R0052 and Bifidobacterium longum R0175) in rats and human subjects. Br. J. Nutr. 105, 755-764. doi: 10.1017/s0007114510004319

Miller, G., and Fleischman, D. (2016). "Do sexually transmitted pathogens manipulate human sexual behavior?," in The Human Behavior and Evolution Society, 28th Annual Meeting (Vancouver).

Mutic, S., Parma, V., Brünner, Y. F., and Freiherr, J. (2016). You smell dangerous: communicating fight responses through human chemosignals of aggression. Chem. Senses 41, 35-43. doi: 10.1093/chemse/bjv058

Nave, G., Nadler, A., Zava, D., and Camerer, C. (2017). Single dose testosterone administration impairs cognitive reflection in men. Psychol. Sci. 28, 1398-1407. doi: 10.1177/0956797617709592

Novotná, M., Havlíček, J., Smith, A. P., Kolbeková, P., Skallová, A., Klose, J., et al. (2008). Toxoplasma and reaction time: role of toxoplasmosis in the origin, preservation and geographical distribution of Rh blood group polymorphism. Parasitology 135, 1253-1261. doi: 10.1017/s003118200800485x

Pearce, B. D., Kruszon-Moran, D., and Jones, J. L. (2012). The relationship between Toxoplasma gondii infection and mood disorders in the third national health and nutrition survey. Biol. Psychiatry 72, 290-295. doi: 10.1016/j.biopsych. 2012.01.003

Phillips, A. C., Carroll, D., Khan, N., and Moss, P. (2008). Cytomegalovirus is associated with depression and anxiety in older adults. Brain Behav. Immun. 22, 52-55. doi: 10.1016/j.bbi.2007.06.012

Prandota, J. (2010). Neuropathological changes and clinical features of autism spectrum disorder participants are similar to that reported in congenital and 
chronic cerebral toxoplasmosis in humans and mice. Res. Autism Spectr. Disord. 4, 103-118. doi: 10.1016/j.rasd.2009.09.007

Prandovszky, E., Gaskell, E., Martin, H., Dubey, J. P., Webster, J. P., and McConkey, G. A. (2011). The neurotropic parasite Toxoplasma gondii increases dopamine metabolism. PLoS One 6:e23866. doi: 10.1371/journal.pone.0023866

Prehn-Kristensen, A., Wiesner, C., Bergmann, T. O., Wolff, S., Jansen, O., Mehdorn, H. M., et al. (2009). Induction of empathy by the smell of anxiety. PLoS One 4:e5987. doi: 10.1371/journal.pone.0005987

Rabin, M. (1993). Incorporating fairness into game theory and economics. Am. Econ. Rev. 83, 1281-1302.

Ravina, E. (2012). Love and loans: the effect of beauty and personal characteristics in credit markets. SSRN Electronic Journal Available online at: https://papers.ssrn.com/sol3/papers.cfm?abstract_id=1107307.

Rilling, J. K., and Sanfey, A. G. (2011). The neuroscience of social decisionmaking. Annu. Rev. Psychol. 62, 23-48. doi: 10.1146/annurev.psych.121208. 131647

Romijn, A. R., and Rucklidge, J. J. (2015). Systematic review of evidence to support the theory of psychobiotics. Nutr. Rev. 73, 675-693. doi: 10.1093/nutrit/nuv025

Ruffle, B. J., and Shtudiner, Z. E. (2015). Are good-looking people more employable? Manage. Sci. 61, 1760-1776. doi: 10.1287/mnsc.2014.1927

Sachs, J., and Malaney, P. (2002). The economic and social burden of malaria. Nature 415, 680-685. doi: 10.1038/415680a

Sagioglou, C., and Greitemeyer, T. (2014). Bitter taste causes hostility. Pers. Soc. Psychol. Bull. 40, 1589-1597. doi: 10.1177/0146167214552792

Sandhu, K. V., Sherwin, E., Schellekens, H., Stanton, C., Dinan, T. G., and Cryan, J. F. (2017). Feeding the microbiota-gut-brain axis: diet, microbiome, and neuropsychiatry. Transl. Res. 179, 223-244. doi: 10.1016/j.trsl.2016.10.002

Schaller, M., and Murray, D. R. (2008). Pathogens, personality, and culture: disease prevalence predicts worldwide variability in sociosexuality, extraversion, and openness to experience. J. Pers. Soc. Psychol. 95, 212-221. doi: 10.1037/00223514.95.1.212

Schaller, M., Murray, D. R., and Bangerter, A. (2015). Implications of the behavioural immune system for social behaviour and human health in the modern world. Philos. Trans. R. Soc. Lond. B Biol. Sci. 370:20140105. doi: 10.1098/rstb.2014.0105

Scholz, J. K., and Sicinski, K. (2015). Facial attractiveness and lifetime earnings: evidence from a cohort study. Rev. Econ. Stat. 97, 14-28. doi: 10.1162/rest_a_00435

Semin, G. R., and de Groot, J. H. B. (2013). The chemical bases of human sociality. Trends Cogn. Sci. 17, 427-429. doi: 10.1016/j.tics.2013.05.008

Sender, R., Fuchs, S., and Milo, R. (2016). Revised estimates for the number of human and bacteria cells in the body. PLoS Biol. 14:e1002533. doi: 10.1371/journal.pbio. 1002533

Sherwin, E., Dinan, T. G., and Cryan, J. F. (2017). Recent developments in understanding the role of the gut microbiota in brain health and disease. Ann. N Y Acad. Sci. doi: 10.1111/nyas.13416 [Epub ahead of print].

Siebler, P. H., Heinze, J. D., Kienzle, D. M., Hale, M. W., Lukkes, J. L., Donner, N. C., et al. (2018). Acute administration of the nonpathogenic, saprophytic bacterium, mycobacterium vaccae, induces activation of serotonergic neurons in the dorsal raphe nucleus and antidepressant-like behavior in association with mild hypothermia. Cell. Mol. Neurobiol. 38, 289-304. doi: 10.1007/s10571-017-0564-3

Simmons, J. P., Nelson, L. D., and Simonsohn, U. (2011). False-positive psychology: undisclosed flexibility in data collection and analysis allows presenting anything as significant. Psychol. Sci. 22, 1359-1366. doi: $10.1177 / 0956797611417632$

Skallová, A., Novotná, M., Kolbeková, P., Gasová, Z., Veselý, V., Sechovská, M., et al. (2005). Decreased level of novelty seeking in blood donors infected with Toxoplasma. Neuro Endocrinol. Lett. 26, 480-486.

Spolaore, E., and Wacziarg, R. (2013). How deep are the roots of economic development? J. Econ. Lit. 51, 325-369. doi: 10.1257/jel.51.2.325

Steenbergen, L., Sellaro, R., van Hemert, S., Bosch, J. A., and Colzato, L. S. (2015). A randomized controlled trial to test the effect of multispecies probiotics on cognitive reactivity to sad mood. Brain Behav. Immun. 48, 258-264. doi: 10.1016/j.bbi.2015.04.003

Stilling, R. M., Dinan, T. G., and Cryan, J. F. (2016). The brain's Geppetto-microbes as puppeteers of neural function and behaviour? J. Neurovirol. 22, 14-21. doi: 10.1007/s13365-015-0355-x
Sudo, N., Chida, Y., Aiba, Y., Sonoda, J., Oyama, N., and Yu, X. N. (2004). Postnatal microbial colonization programs the hypothalamic-pituitary-adrenal system for stress response in mice. J. Physiol. 558, 263-275. doi: 10.1113/jphysiol.2004. 063388

Sugden, K., Moffitt, T. E., Pinto, L., Poulton, R., Williams, B. S., and Caspi, A. (2016). Is Toxoplasma gondii infection related to brain and behavior impairments in humans? Evidence from a population-representative birth cohort. PLoS One 11:e0148435. doi: 10.1371/journal.pone.0148435

Tillisch, K., Mayer, E. A., Gupta, A., Gill, Z., Brazeilles, R., Le Nevé, B., et al. (2017). Brain structure and response to emotional stimuli as related to gut microbial profiles in healthy women. Psychosom. Med. 79, 905-913. doi: 10.1097/psy. 0000000000000493

Torrey, E. F., Bartko, J. J., and Yolken, R. H. (2012). Toxoplasma gondii and other risk factors for schizophrenia: an update. Schizophr. Bull. 38, 642-647. doi: 10.1093/schbul/sbs043

Tybur, J. M., Inbar, Y., Aarøe, L., Barclay, P., Barlow, F. K., de Barra, M., et al. (2016). Parasite stress and pathogen avoidance relate to distinct dimensions of political ideology across 30 nations. Proc. Natl. Acad. Sci. U S A 113, 12408-12413. doi: 10.1073/pnas.1607398113

Wang, X., Geng, L., Qin, J., and Yao, S. (2016). The potential relationship between spicy taste and risk seeking. Judgm. Decis. Mak. 11, 547-553.

Wang, X., Zhang, L., Lei, Y., Liu, X., Zhou, X., Liu, Y., et al. (2014). Meta-analysis of infectious agents and depression. Sci. Rep. 4:4530. doi: 10.1038/srep04530

Webster, J. P. (2001). Rats, cats, people and parasites: the impact of latent toxoplasmosis on behaviour. Microbes Infect. 3, 1037-1045. doi: 10.1016/s12864579(01)01459-9

Webster, J. P. (2007). The effect of Toxoplasma gondii on animal behavior: playing cat and mouse. Schizophr. Bull. 33, 752-756. doi: 10.1093/schbul/sbl073

Weinersmith, K. L., and Earley, R. L. (2016). Better with your parasites? Lessons for behavioural ecology from evolved dependence and conditionally helpful parasites. Anim. Behav. 118, 123-133. doi: 10.1016/j.anbehav.2016.06.004

Weiss, L. M., and Dubey, J. P. (2009). Toxoplasmosis: a history of clinical observations. Int. J. Parasitol. 39, 895-901. doi: 10.1016/j.ijpara.2009. 02.004

Williams, J., Stönner, C., Wicker, J., Krauter, N., Derstroff, B., Bourtsoukidis, E., et al. (2016). Cinema audiences reproducibly vary the chemical composition of air during films, by broadcasting scene specific emissions on breath. Sci. Rep. 6:25464. doi: 10.1038/srep25464

Wu, G. D., Chen, J., Hoffmann, C., Bittinger, K., Chen, Y.-Y., Keilbaugh, S. A., et al. (2011). Linking long-term dietary patterns with gut microbial enterotypes. Science 334, 105-108. doi: 10.1126/science.1208344

Wyatt, T. D. (2015). The search for human pheromones: the lost decades and the necessity of returning to first principles. Proc. Biol. Sci. 282:20142994. doi: 10.1098/rspb.2014.2994

Yeshurun, Y., and Sobel, N. (2010). An odor is not worth a thousand words: from multidimensional odors to unidimensional odor objects. Annu. Rev. Psychol. 61, 219-241. doi: 10.1146/annurev.psych.60.110707.163639

Yolken, R. H., Jones-Brando, L., Dunigan, D. D., Kannan, G., Dickerson, F., Severance, E., et al. (2014). Chlorovirus ATCV-1 is part of the human oropharyngeal virome and is associated with changes in cognitive functions in humans and mice. Proc. Natl. Acad. Sci. U S A 111, 16106-16111. doi: 10.1073/pnas.1418895111

Zhou, W., and Chen, D. (2009). Fear-related chemosignals modulate recognition of fear in ambiguous facial expressions. Psychol. Sci. 20, 177-183. doi: 10.1111/j. 1467-9280.2009.02263.x

Conflict of Interest Statement: The author declares that the research was conducted in the absence of any commercial or financial relationships that could be construed as a potential conflict of interest.

The reviewer SR and handling Editor declared their shared affiliation.

Copyright $\odot 2018$ Houdek. This is an open-access article distributed under the terms of the Creative Commons Attribution License (CC BY). The use, distribution or reproduction in other forums is permitted, provided the original author(s) and the copyright owner are credited and that the original publication in this journal is cited, in accordance with accepted academic practice. No use, distribution or reproduction is permitted which does not comply with these terms. 